\title{
Stratigraphic Units of Shallow Unconsolidated Deposits in Deadwood, South Dakota, Delineated by Real-Time Kinematic Surveys
}

By Wyatt S. Tatge, Colton J. Medler, William G. Eldridge, and Joshua F. Valder

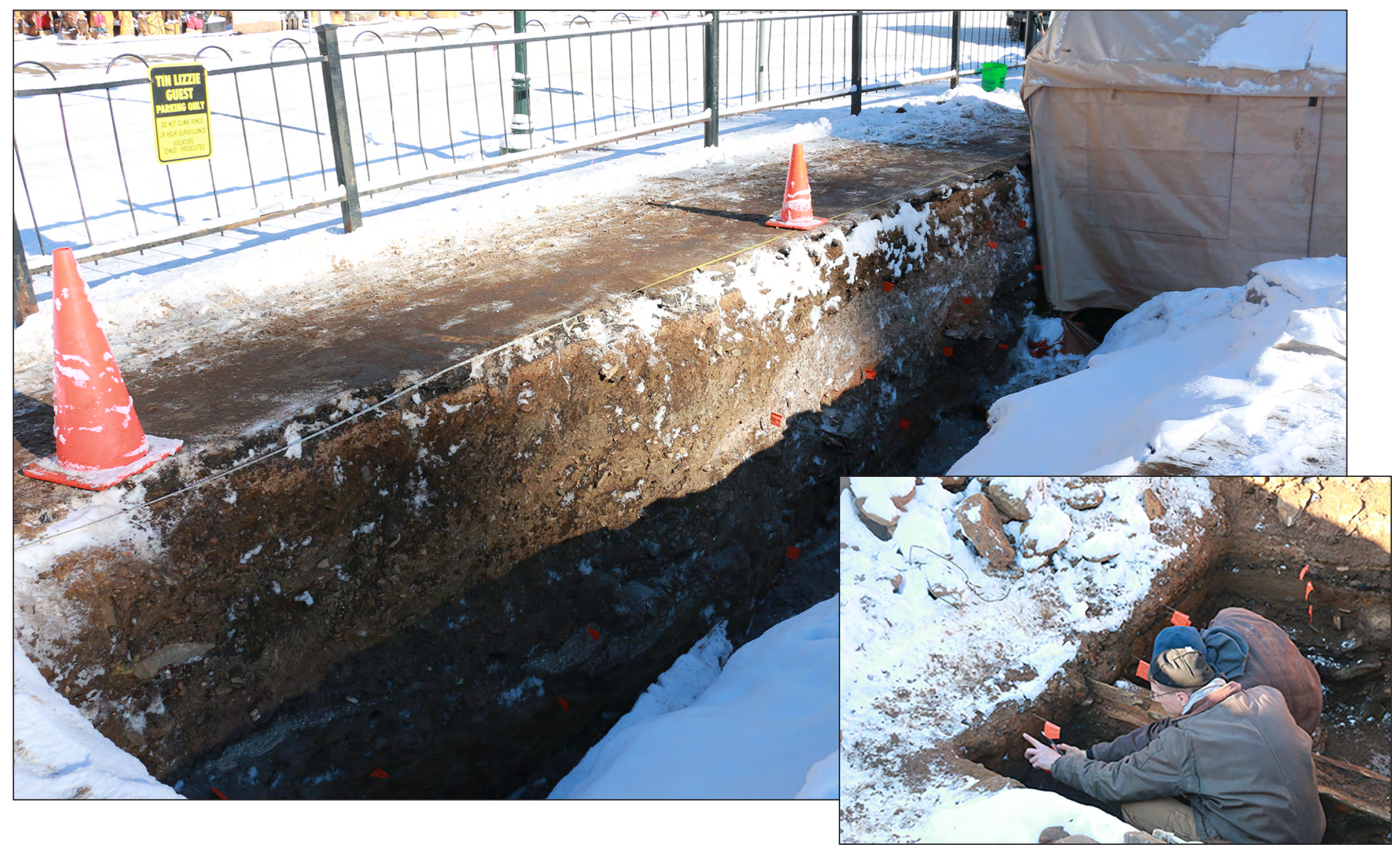

Pamphlet to accompany

Scientific Investigations Map 3459
Photographs showing primary excavation pit along Main Street and (inset) U.S. Geological Survey hydrologists observing and describing the stratigraphic units. Photographs taken in Deadwood, South Dakota, on January 28, 2020, by Joshua Valder, U.S. Geological Survey.

U.S. Department of the Interior

U.S. Geological Survey 


\title{
U.S. Department of the Interior \\ DAVID BERNHARDT, Secretary
}

\section{U.S. Geological Survey James F. Reilly II, Director}

\author{
U.S. Geological Survey, Reston, Virginia: 2020
}

For more information on the USGS - the Federal source for science about the Earth, its natural and living resources, natural hazards, and the environment—visit https://www.usgs.gov or call 1-888-ASK-USGS.

For an overview of USGS information products, including maps, imagery, and publications, visit https://store.usgs.gov/.

Any use of trade, firm, or product names is for descriptive purposes only and does not imply endorsement by the U.S. Government.

Although this information product, for the most part, is in the public domain, it also may contain copyrighted materials as noted in the text. Permission to reproduce copyrighted items must be secured from the copyright owner.

Suggested citation:

Tatge, W.S., Medler, C.J., Eldridge, W.G., and Valder, J.F., 2020, Stratigraphic units of shallow unconsolidated deposits in Deadwood, South Dakota, delineated by real-time kinematic surveys: U.S. Geological Survey Scientific Investigations Map 3459, pamphlet 7 p., 1 sheet, https://doi.org/10.3133/sim3459.

ISSN 2329-132X (online) 


\section{Acknowledgments}

The authors wish to acknowledge the City of Deadwood for assistance in completing this study. Specifically, thanks to Michael Runge, City of Deadwood archivist, and Kevin Kuchenbecker, City of Deadwood historic preservation officer, for all their insightful comments and explanations pertaining to Deadwood history.

The authors also wish to acknowledge several personnel at the U.S. Geological Survey, including Ryan Thompson and Joel Peterson, who assisted with technical questions in collecting and processing the survey data. Additionally, thanks to Grady Ball and Tara Williams-Sether for providing insightful edits and comments for this report. 



\section{Contents}

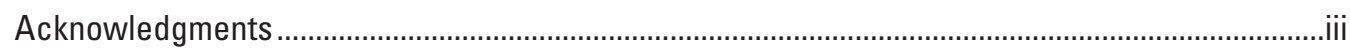

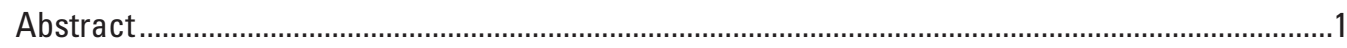

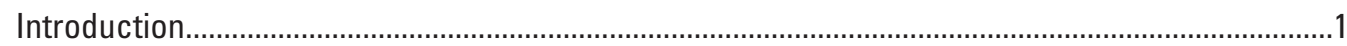

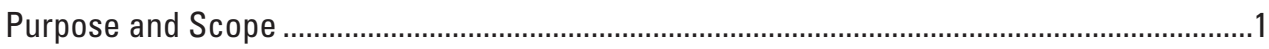

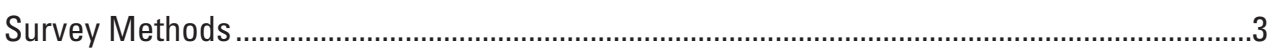

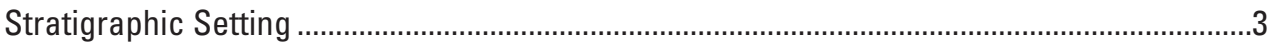

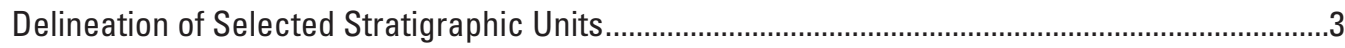

Field Methods for Describing Stratigraphic Units....................................................................

Map Interpolation of Stratigraphic Changes ........................................................................... 4

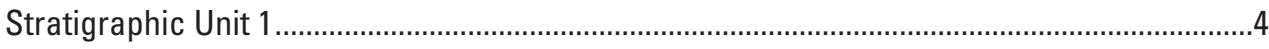

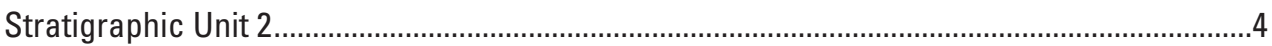

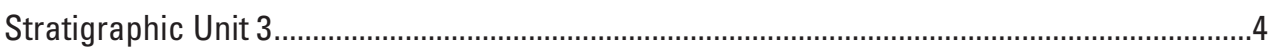

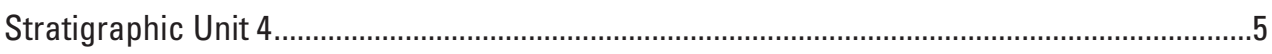

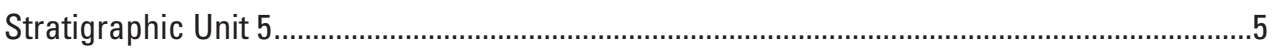

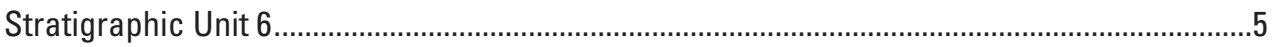

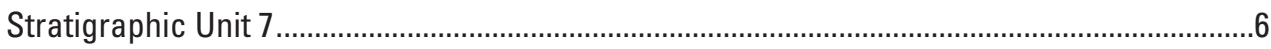

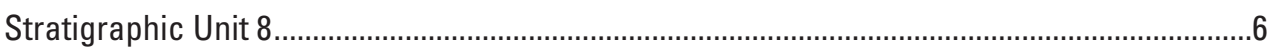

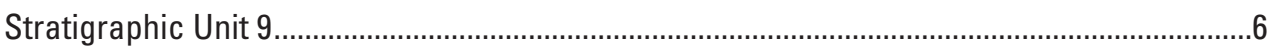

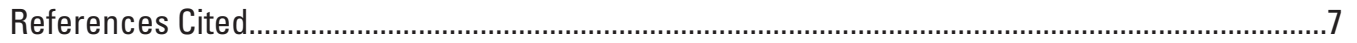

\section{Figures}

1. Study area map showing excavation sites in late 2019 and early 2020 along Main Street in Deadwood, South Dakota ......................................................................

\section{Tables}

1. Survey points collected for delineation of selected stratigraphic units ...........................1 


\section{Conversion Factors}

U.S. customary units to International System of Units

\begin{tabular}{|c|c|c|}
\hline Multiply & By & To obtain \\
\hline \multicolumn{3}{|c|}{ Length } \\
\hline inch (in) & 2.54 & centimeter $(\mathrm{cm})$ \\
\hline inch (in) & 25.4 & millimeter $(\mathrm{mm})$ \\
\hline foot $(\mathrm{ft})$ & 0.3048 & meter (m) \\
\hline mile (mi) & 1.609 & kilometer $(\mathrm{km})$ \\
\hline
\end{tabular}

International System of Units to U.S. customary units

\begin{tabular}{lccc}
\hline & Multiply & By & To obtain \\
\hline & Length & \\
\hline meter $(\mathrm{m})$ & 3.281 & foot $(\mathrm{ft})$ & \\
\hline
\end{tabular}

\section{Datum}

Vertical coordinate information is referenced to North American Vertical Datum of 1988 (NAVD 88).

Horizontal coordinate information is referenced to the Universal Transverse Mercator (UTM) Zone 13.

Elevation, as used in this report, refers to distance above the vertical datum.

\section{Abbreviations}

RTK real-time kinematic

USGS U.S. Geological Survey

UTM Universal Transverse Mercator 


\title{
Stratigraphic Units of Shallow Unconsolidated Deposits in Deadwood, South Dakota, Delineated by Real-Time Kinematic Surveys
}

\author{
By Wyatt S. Tatge, Colton J. Medler, William G. Eldridge, and Joshua F. Valder
}

\section{Abstract}

The City of Deadwood, South Dakota, has been working on a new archeological investigation in preparation for economic growth and expansion within the city limits, through the Deadwood Historic Preservation Office. During the excavation process, buried artifacts and historical features from the late 1800 s have been uncovered. The stratigraphy of shallow unconsolidated deposits in the city of Deadwood, S. Dak., was surveyed on January 29, 2020, using real-time kinematic survey methods and described to identify variations in geologic material, thickness, and depth from the land surface in support of archeological studies by the city. The findings of the study will provide city managers and the public with reliable and impartial information for their use by advancing field or analytical methodology and understanding of hydrologic processes in the study area. The primary excavation site was surveyed, and stratigraphic units were delineated from changes in material properties or depositional environment. The primary excavation site consisted of nine stratigraphic units; however, some units were not consistent along the length of the excavation and pinched out along the cross section. Survey data points also were collected for artifacts and other sites of interest. The shallow surficial geology in the study area was affected by human construction, fires, and flooding.

\section{Introduction}

The City of Deadwood, South Dakota, has been working on a new archeological investigation in preparation for economic growth and expansion within the city limits, through the Deadwood Historic Preservation Office. During the excavation process by the City of Deadwood, buried artifacts and historical features from the late 1800s have been uncovered. Documenting and mapping geologic materials is an important aspect in understanding the past. Over the years, flooding events deposited large amounts of sediment, and the fires throughout the city deposited a layer of ash. These events can be observed in the stratigraphy of shallow unconsolidated deposits in the city. Stratigraphy at this site refers to the changes in the sedimentary units that were observed in the excavations. This stratigraphy was surveyed on January 29, 2020, using real-time kinematic (RTK) survey methods and described to identify variations in geologic material, thickness, and depth from the land surface in support of archeological studies by the city. The findings of the study will provide city managers and the public with reliable and impartial information for their use by advancing field or analytical methodology and understanding of hydrologic processes in the study area.

The study area included several archeological sites along Main Street in Deadwood (fig. 1), excavated and studied in late 2019 and early 2020. The primary excavation site was 120 feet (ft) long and $3 \mathrm{ft}$ wide in a parking lot south of Main Street (fig. 1; inset $H$, sheet 1, available for download at https://doi.org/10.3133/sim3459). Several smaller sites were surveyed in the study area to provide references for future archeological excavations and studies.

The primary excavation site was surveyed by the U.S. Geological Survey (USGS), and stratigraphic units were delineated from changes in material properties or depositional environment. The primary excavation site consisted of nine stratigraphic units; however, some units were not consistent along the length of the excavation and pinched out along the cross section. Additionally, the cross section contained several human-built structures such as foundations, basements, and walls that formed boundaries for some stratigraphic units. The prominent stratigraphic units at the primary site are described in the "Delineation of Selected Stratigraphic Units" section of this report.

\section{Purpose and Scope}

The purpose of this report is to describe and delineate the stratigraphic units of the shallow unconsolidated deposits at an archeological excavation site in Deadwood, S. Dak. Survey points delineating the stratigraphy were collected by RTK survey methods on January 29, 2020, and are listed in table 1 (available for download at https://doi.org/10.3133/sim3459). This report describes the stratigraphic setting and the delineation of selected stratigraphic units. 

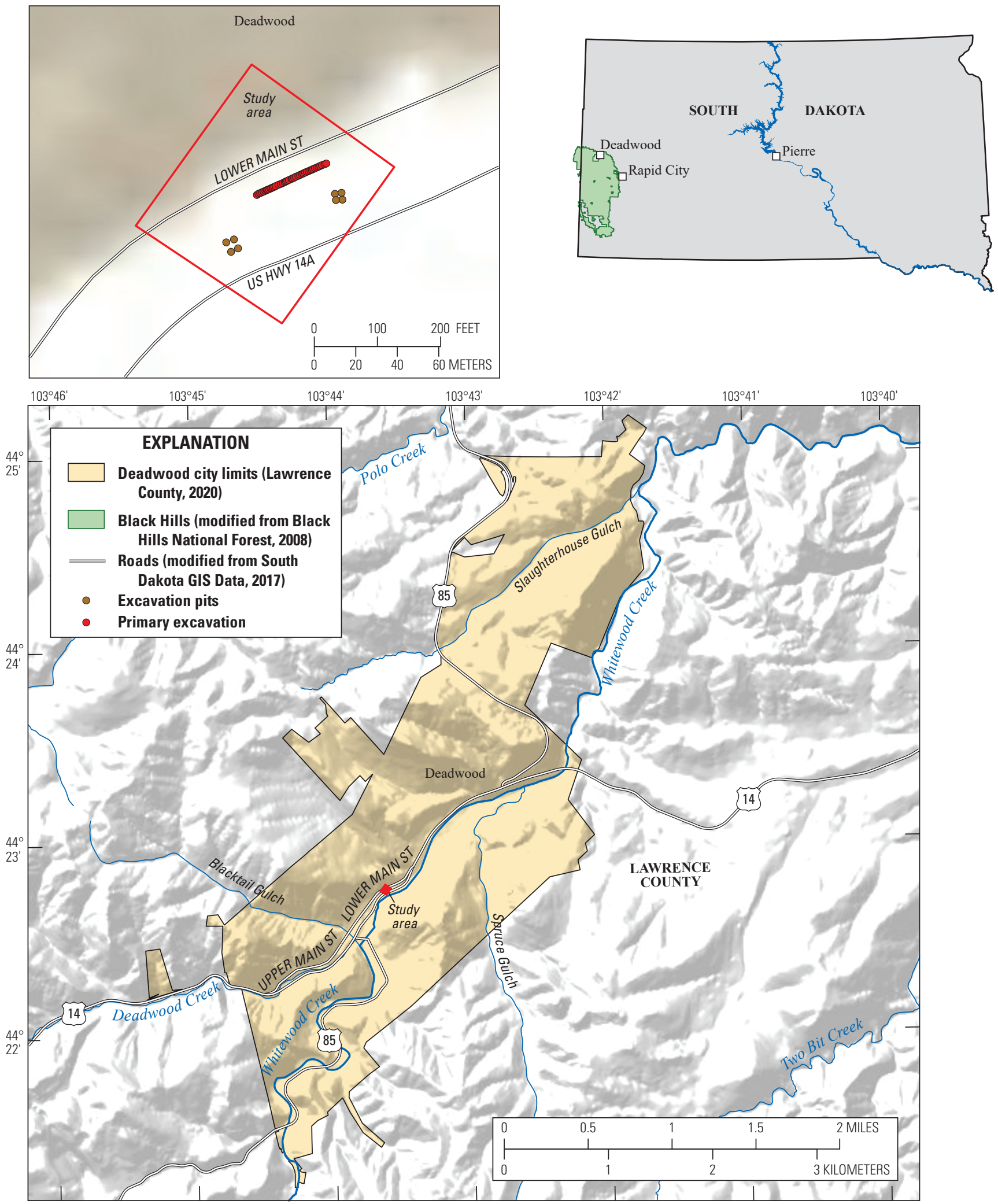

Base map modified from Esri (copyright 2020), U.S. Geological Survey, South Dakota, and other digital sources, various dates Map projection: UTM, Zone $13 \mathrm{~N}$

Horizontal datum is North American Datum of 1983

Figure 1. Study area map showing excavation sites in late 2019 and early 2020 along Main Street in Deadwood, South Dakota. 


\section{Survey Methods}

A survey-grade real-time Global Navigation Satellite System (Rydlund and Densmore, 2012) was used to provide the three-dimensional position of stratigraphic contacts and points of interest in the study area. Survey points were measured on January 29, 2020, using single-base RTK survey methods. Surveys using RTK methods use a base station to provide real-time differential corrections from signals received at the base to signals received at the mobile roving unit (Rydlund and Densmore, 2012). Equipment used for the survey included a Topcon HiPer GA roving receiver and a single stationary receiver used as a base station. Antenna heights, for the base station and rover receiver, were $4.06 \mathrm{ft}$ (1.238 meters $[\mathrm{m}])$ and $6.562 \mathrm{ft}(2.000 \mathrm{~m})$, respectively. Survey points were referenced to the North American Datum of 1983 Universal Transverse Mercator (UTM) Zone 13 coordinate system, and the geoid model was GEOID18 (National Geodetic Survey, 2020a). The base station collected static position information for 4 hours and 28 minutes. Survey points were adjusted based on a corrected base station reference location determined using the Online Positioning User Service provided by the National Geodetic Survey (National Geodetic Survey, 2020b). Corrected base station location accuracy was $0.03 \mathrm{ft}(0.01 \mathrm{~m})$ horizontally and $0.1 \mathrm{ft}(0.03 \mathrm{~m})$ vertically, which was assumed also to represent the accuracy of all survey points. The base station location correction was applied to all survey points using Topcon Tools software version 8.2.3 (Topcon, 2020).

Survey data points were collected at stratigraphic contacts, artifacts, and other sites of interest (table 1). Artifacts surveyed in the excavation pit included a flume, a plank, and a tree stump. Other sites of interest (not shown on map) were test pits 1 and 2, street points, building points, and streetlights. Listed in table 1 are the survey points by name, unit identifier, coordinates in UTM Zone 13 (in feet), elevation (in feet above the North American Vertical Datum of 1988), and a general description of each survey point group.

\section{Stratigraphic Setting}

The stratigraphic setting of the study area is the northern Black Hills of South Dakota. Formed by the Laramide orogeny, the Black Hills are an elongated domal uplift about 125 miles long in the northwest-southeast direction and 60 miles wide in the southwest-northeast direction (Feldman and Heimlich, 1980). Precambrian-age (more than 541 million years ago; U.S. Geological Survey Geologic Names Committee, 2018; Cohen and others, 2019) igneous and metamorphic rocks, which form the core of the Black Hills, became exposed after the overlying younger sedimentary rocks were eroded after orogenic uplift (Carter and others, 2001a, b). The city inhabits an exposure of igneous rock in the northern Black Hills and is oriented alongside Whitewood and Deadwood Creeks (fig. 1; Lisenbee and others, 2015). Unconformably overlying the igneous and metamorphic rocks in the City of
Deadwood is the Deadwood Formation (Redden and DeWitt, 2008). The Lower Ordovician and Upper Cambrian Deadwood Formation consists of glauconitic sandstone, shale, siltstone, and conglomerate that ranges in thickness between 0 and approximately $660 \mathrm{ft}$ (Redden and DeWitt, 2008).

The surficial geology of the study area is composed of unconsolidated to loosely consolidated terrace deposits, some of which are boulder sized (Lisenbee and others, 2015). Whitewood Creek is about $160 \mathrm{ft}$ south of the study area and flows northeast. Terrace deposits, about 40-60 ft above stream drainages, have a maximum thickness of about $20 \mathrm{ft}$, whereas alluvial deposits within the study area have a maximum thickness of about $35 \mathrm{ft}$ (Lisenbee and others, 2015).

The shallow surficial geology in the study area has been affected by human construction, fires, and flooding. The city was established in 1876 during a gold rush to the region (Deadwood Chamber of Commerce, 2020). Construction of several commercial and residential structures began soon after the city was established. In 1877, the development of Deadwood's Chinatown began near the study area, along the present-day Main Street. In 1879, a fire destroyed most of the city's buildings, but by the following year, the town had been partly rebuilt with brick and stone structures replacing wooden buildings. In the spring of 1883, a flood caused by snowmelt and heavy rains demolished many of the reconstructed buildings (Driscoll and others, 2010), and a subsequent fire in 1894 destroyed many Main Street businesses. After the fire, sandstone building materials were used for some reconstruction, notably the Bullock Hotel. Heavy spring snows and rains caused flooding of the city again in 1904, 1907, and 1965 (Driscoll and others, 2010). Restoration efforts that included street reconstruction and commercial building development began downtown in 1987. In 2001, remnants of Chinatown were discovered during construction of a parking garage along Main Street, and excavation efforts supporting archeological and historical studies of the city began the same year.

\section{Delineation of Selected Stratigraphic Units}

The stratigraphic changes in the primary excavation site were described and surveyed on January 29, 2020. The descriptions were used to delineate nine stratigraphic units in the primary excavation site. Each unit was mapped in cross section and the stratigraphy of the nine units was described.

\section{Field Methods for Describing Stratigraphic Units}

To describe each stratigraphic unit, multiple USGS hydrologists were onsite during the excavation to make observations. Each stratigraphic unit was described by observing color, texture (grain size, sorting, and shape), fabric, small 
scale sedimentary structures, mineralogical composition, presence of cultural fill, and other distinguishing features (Compton, 1985; Freeman, 2009). Placement of stratigraphic contacts was determined based upon the observations recorded in the field by the USGS hydrologists and were subsequently surveyed as described above in the "Survey Methods" section.

\section{Map Interpolation of Stratigraphic Changes}

The surveyed stratigraphic and artifact data are mapped in sheet 1 . The survey data were projected using the UTM Zone 13 coordinate system. The cross sections were oriented southwest to northeast along the excavation and separated into three blocks to visualize the stratigraphic changes of the shallow unconsolidated deposits (insets $A-D$, sheet 1). Cross sections $A-A^{\prime}, B-B^{\prime}$, and $C-C^{\prime}$ were based on the stratigraphic descriptions, photographs taken by the USGS of the excavation, and the RTK survey data. Depths, thicknesses, and the topographic profile were determined using the RTK survey data along the excavation. In some units, interpolation of the cross-section lines was based on the photographs of the excavation and follows the contacts between the stratigraphic units. The abrupt ending of a few of the stratigraphic units was caused by human-built structures such as basement walls. Multiple artifacts were uncovered in the excavation, including a flume, floorboards, sandstone bricks, a plank, and a tree stump. The location of each artifact was labeled on the cross sections.

\section{Stratigraphic Unit 1}

Unit 1 is the uppermost stratigraphic unit and is described in detail in inset $E$ of sheet 1. Unit 1 is unconsolidated and consists of a light to dark brown clay to coarse-grained silt matrix intermixed with sand (fine to coarse), pebbles (mostly $1 \mathrm{inch}$ in diameter; ranging from 0.1 to 2.5 inches in diameter), cobbles, and boulders (from 3 to less than 6 inches in diameter). Clay particles were too fine for visual mineral classification; however, silt and sand in the unit consist of mostly wellrounded and poorly sorted quartz, feldspar, organic matter, and iron minerals. Pebbles are angular and poorly to well-sorted grains consisting of quartz and weathered metamorphic rock (schist) fragments of uniform size (about 1 inch in diameter). The largest particles, cobbles and boulders, are angular and poorly sorted weathered metamorphic rock (schist) and sandstone (likely the Cambrian- and Ordovician-age Deadwood Formation). Samples did not effervesce when in contact with hydrochloric acid. The clay and silt matrix has low cohesion. Unit 1 generally fines upward, has no sedimentary structures (laminations, crossbedding), and in some areas, has no grading. The unit also contains cultural fill (bricks, plaster, concrete, porcelain, and glass) of various sizes (from 0.1 to 10 inches in diameter) that changes content throughout the trench (inset $D$, sheet 1).
Unit 1 was characterized by multiple layers of engineered fill (uniformly sized pebbles about 1 inch in diameter) overlying and intermixed with cultural fill (bricks, plaster, porcelain, and glass). Some engineered fill deposits may have been used to bury several layers of cultural fill, whereas other fill deposits may have been used for road construction. Cultural fill content is greatest in block $\mathrm{B}$ (inset $D$, sheet 1 ) and decreases to the southwest (block A) and northeast (block C). Unit 1 is present in all three blocks (inset $D$, sheet 1 ) and its thickness, obtained from the RTK survey, ranges from 0.80 to $3.16 \mathrm{ft}$, with a mean of $1.70 \mathrm{ft}$. The maximum measured thickness was $3.16 \mathrm{ft}$ in block A (inset $D$, sheet 1 ).

\section{Stratigraphic Unit 2}

Unit 2 underlies unit 1 and is described in detail in inset $E$ of sheet 1 . The unit is unconsolidated and consists of white to light gray to light brown fine-grained silt to very coarsegrained sand. Additionally, aggregated clay and cultural fill (glass, metal objects, wood chunks, and porcelain) are intermixed throughout the unit. The clay particles were too fine for mineral classification; however, the silt and sand particles are mostly well-rounded and poorly sorted calcium carbonate and quartz. The white to light gray color is from calcium carbonate precipitate that strongly effervesced when in contact with hydrochloric acid. The silt and sand matrix has low cohesion. The unit is not graded and shows no sedimentary structures (laminations, crossbedding). Additionally, the unit has high cultural fill (bricks, plaster, concrete, porcelain, and glass) content that ranges in size (from 0.1 to 10 inches in diameter) where present in the trench (inset $D$, sheet 1 ).

Unit 2 was distinguished from other units by its white to light gray color (calcium carbonate) and high cultural fill content. The size and content of cultural fill materials are generally greatest in the central part of block B in inset $D$ of sheet 1 and decrease southwest and northeast. Unit 2 is present in blocks A and B in inset $D$ of sheet 1 and pinched out west of an underground concrete wall in the eastern part of block B. The thickness of unit 2, obtained from the RTK survey, ranges from 0.44 to $2.75 \mathrm{ft}$, with a mean of $1.38 \mathrm{ft}$. The maximum measured thickness was $2.75 \mathrm{ft}$ in block A (inset $D$, sheet 1 ).

\section{Stratigraphic Unit 3}

Unit 3 underlies unit 2 and is described in detail in inset $E$ of sheet 1. Unit 3 is unconsolidated and consists of light brown to brown clay to fine-grained silt with fine to coarse pebbles, aggregated clay (as much as $1 \mathrm{inch}$ in diameter), and plant roots. Clay particles were too small for mineral classification; however, silt consists mostly of well-rounded and well-sorted quartz, feldspar, organic matter, and iron minerals. Pebbles are subangular to angular and poorly sorted quartz and weathered metamorphic rock (schist) fragments. Samples did not effervesce when in contact with hydrochloric acid. The clay and silt matrix of unit 3 has low to moderate cohesion and 
is greatest at the top of the unit. Unit 3 generally fines upward (clay aggregates at the top) with no sedimentary structures (laminations, crossbedding). Plant roots are limited to aggregated clay at the top of the unit.

Unit 3 was characterized by roots, aggregated clay, and a lack of cultural fill materials. The uppermost part of the unit contains abundant plant roots mixed with aggregated clay consisting of mostly organic matter (assumed based on brown to dark brown color), which indicates soil development for plants, most likely grass. Unit 3 was probably a fill layer for underlying cultural fill materials that developed into a soil and encouraged plant growth. The unit was first observed halfway through block A in inset $D$ of sheet 1 and abruptly ended on the western side of an underground concrete wall in the eastern part of block B. The thickness of unit 3, obtained from the RTK survey, ranges from 0.25 to $0.91 \mathrm{ft}$, with a mean of $0.58 \mathrm{ft}$. The maximum measured thickness was $0.91 \mathrm{ft}$ in block A (inset $D$, sheet 1).

\section{Stratigraphic Unit 4}

Unit 4 underlies unit 3 and is described in detail in inset $E$ of sheet 1. Unit 4 is unconsolidated and consists of light brown to brown fine-grained silt to very coarse-grained sand with intermixed clay and very fine to coarse pebbles. Clay particles were too small for mineral classification; however, silt and sand consist mostly of well-rounded and well-sorted quartz, muscovite, biotite, feldspar, organic matter, and iron minerals. Pebbles are well-rounded to subangular to angular and poorly sorted quartz and metamorphic rock (schist) fragments. Samples from unit 4 did not effervesce when in contact with hydrochloric acid. Silt and sand have low cohesion because of the high sand content. Unit 4 generally fines upward with no sedimentary structures (laminations, crossbedding). Unit 4 also has high cultural fill that includes shards of glass, pieces of porcelain, refined metal, brick, plaster, and wood of variable size (less than 2 inches in diameter).The cultural fill ranges in size (from 0.1 to 10 inches in diameter) where present in the trench (inset $D$, sheet 1 ).

Unit 4 was characterized by its high cultural fill content. The size and content of cultural fill materials in unit 4 generally is greatest in the central part of block B in inset $D$ of sheet 1 and decreases southwest and northeast. Unit 4 was first observed three-quarters of the way through block A in inset $D$ of sheet 1 and, similar to unit 3, abruptly ends on the western side of an underground concrete wall in the eastern part block B. The thickness of unit 4, obtained from the RTK survey, ranges from 0.22 to $0.74 \mathrm{ft}$, with a mean of $0.46 \mathrm{ft}$. The maximum measured thickness was $0.74 \mathrm{ft}$ in block A (inset $D$, sheet 1).

\section{Stratigraphic Unit 5}

Unit 5 underlies unit 4 and is described in detail in inset $E$ of sheet 1. Unit 5 is unconsolidated and consists of light brown to brown clay to fine-grained silt with fine $(0.1 \mathrm{inch}$ in diameter) to very coarse pebbles (1.5 inches in diameter) and fine cobbles ( 2.5 inches in diameter). Clay particles were too small for mineral classification; however, silt largely consists of well-rounded and well-sorted quartz, feldspar, organic matter, and iron minerals. Pebbles are subangular to angular and poorly sorted quartz and metamorphic rock (schist) fragments. Samples from unit 5 did not effervesce when in contact with hydrochloric acid. The clay and silt matrix has greater clay content than overlying layers and indicates moderate cohesion. Unit 5 is not graded and shows no sedimentary structures (laminations, crossbedding). The base of unit 5 contains cultural fill (glass, porcelain, metal objects, brick, plaster, and wood chunks) that is smaller in size than in overlying units.

Unit 5 was characterized by its low cultural fill content and is relatively thick compared to unit 3 . The content of cultural fill materials at the base of the unit is smaller, and in less abundance, than overlying units and decreases from west to east in the trench (inset $D$, sheet 1). Unit 5 was most likely a fill layer used to cover cultural fill. Unit 5 is in blocks A and $\mathrm{B}$ of the primary excavation and abruptly ends on the western side of an underground concrete wall in the eastern part of block B (inset $D$, sheet 1 ). The thickness of unit 5 , obtained from the RTK survey, ranges from 0.38 to $2.50 \mathrm{ft}$, with a mean of $1.20 \mathrm{ft}$. The maximum measured thickness was $2.50 \mathrm{ft}$ in block A (inset $D$, sheet 1). The thickness of unit 5 is about two times greater than the overlying unit 3 .

\section{Stratigraphic Unit 6}

Unit 6 underlies unit 5 and is described in detail in inset $E$ of sheet 1. Unit 6 is unconsolidated and consists of a light orange to gray fine-grained silt to medium-grained sand matrix with light brown to brown clay and medium pebbles $(0.5$ inch in diameter) to large boulders (6 to 10 inches in diameter) at the base of the layer. Clay particles were too small for mineral classification; however, silt and sand consist mostly of well-rounded to subangular to angular and well-sorted quartz, muscovite, biotite, potassium feldspar, organic matter, and iron minerals. The pebble- to boulder-sized material consists of well-rounded to subangular to angular and poorly sorted quartz and metamorphic rock (schist and phyllite) fragments. Samples from unit 6 did not effervesce when in contact with hydrochloric acid. The clay and silt have a high clay content at the upper part of the unit and indicate moderate to high cohesion; however, other parts of unit 6 have low to moderate cohesion where the silt and sand content increases (low clay content). Unit 6 generally fines upward, from cobbles and boulders at its base to clay and silts and the top. The top of unit 6 has small laminations (less than 0.1 inch) of alternating orange (oxidized iron) and gray layers superimposed on 
small- to large-scale crossbedding. The top also contains small (less than 0.25 inch in diameter) pieces of burnt wood that disintegrate when removed from the clay and silt matrix.

Unit 6 was distinguished from other units by its sedimentary structures and lack of landfill material. Sedimentary structures, commonly associated with flowing water (laminations, crossbedding), indicate a fluvial source, such as a nearby stream. The small pieces of burnt wood likely originated from a previous fire event, deposited by Whitewood Creek during low-flow conditions. Unit 6 was mapped starting from the middle of block $A$ and it terminates at an underground concrete wall in the eastern part of block B (inset $D$, sheet 1). The thickness of unit 6 , obtained from the RTK survey, ranges from 0.63 to $1.94 \mathrm{ft}$, with a mean of $1.25 \mathrm{ft}$. The maximum measured thickness was $1.94 \mathrm{ft}$ in block B (inset $D$, sheet 1 ).

\section{Stratigraphic Unit 7}

Unit 7 underlies unit 1 and is described in detail in inset $E$ of sheet 1. The unit is unconsolidated and consists of a light brown to dark brown to black clay to coarse-grained silt matrix with very fine- to very coarse-grained sand, very fine to very coarse pebbles, cobbles, and boulders (less than 20 inches in diameter). Clay particles were too small for mineral classification; however, clay at the basal part of unit 7 has high organic matter content based on its dark brown to black color. Silt and sand consist mostly of well-rounded to subangular and well-sorted quartz, organic matter, muscovite, biotite, potassium feldspar, and iron minerals. The pebble- to boulder-sized material consists of subangular to angular and poorly sorted quartz and metamorphic rock (schist and phyllite) fragments. Samples from unit 7 did not effervesce when in contact with hydrochloric acid. The clay and silt matrix has low to moderate cohesion, which increases downward throughout the unit as clay content increases. Unit 7 has no grading or sedimentary structures (laminations, crossbedding), but clay at the base contains a few large particles. The unit also contains cultural fill (glass, porcelain, metal objects, brick, plaster, and wood chunks) and many small (less than 0.5 inch in diameter) to large (greater than 20 inches in diameter) concrete fragments.

Unit 7 was distinguished by its poorly sorted range of particle sizes, its concrete fragment content, and its position in the primary excavation. The unit is the most poorly sorted and has the greatest range in particle size of all units, and it contains concrete fragments not observed in other units containing cultural fill. Unit 7 is limited to block B, between two underground concrete walls (inset $D$, sheet 1), and seems to be a construction fill layer. The thickness of unit 7 ranges from 2.5 to $3.6 \mathrm{ft}$, with a mean of $3.2 \mathrm{ft}$. The maximum measured thickness was $3.6 \mathrm{ft}$ in block B (inset $D$, sheet 1).

\section{Stratigraphic Unit 8}

Unit 8 underlies unit 1 and is described in detail in inset $E$ of sheet 1 . Unit 8 is unconsolidated and consists of a dark brown to black clay to medium-grained silt matrix with fineto medium-grained sand and fine pebbles $(0.25$ inch in diameter) to large boulders ( 8 inches in diameter). Clay particles were too small for mineral classification, but the clay has high organic matter content based on its dark brown to black color. Silt and sand largely consist of well-rounded to subangular and well-sorted quartz, organic matter, muscovite, biotite, and iron minerals. The pebble- to boulder-sized material consists of subrounded to subangular to angular and poorly sorted quartz and metamorphic rock (schist and phyllite) fragments. Samples did not effervesce when in contact with hydrochloric acid. The clay and silt matrix has moderate cohesion. Unit 8 has no grading or sedimentary structures (laminations, crossbedding). The unit contains less cultural fill (glass, porcelain, metal objects, brick, plaster, and wood chunks) than unit 7 and has small (less than 0.5 inch in diameter) to medium (1.5 inches in diameter) concrete fragments.

Unit 8 was distinguished by its concrete fragment content and position in the primary excavation. The size and content of concrete fragments in unit 8 are less than in unit 7 and do not show the same range of particle sizes. Unit 8 was only mapped in block $\mathrm{C}$ on the eastern side of an underground concrete wall (inset $D$, sheet 1 ), and seemed to be used as a construction fill layer. The thickness of unit 8 , obtained from the RTK survey, ranges from 0.77 to $2.61 \mathrm{ft}$, with a mean of $1.85 \mathrm{ft}$. The maximum measured thickness was $2.61 \mathrm{ft}$ (inset $D$, sheet 1 ).

\section{Stratigraphic Unit 9}

Unit 9 is the lowermost unit and is described in detail in inset $E$ of sheet 1. Unit 9 is unconsolidated and contains dark brown to dark reddish-brown clay to fine-grained silt with coarse sand and small cobbles ( 2 to 3 inches in diameter) to large boulders (12 to 16 inches in diameter). Clay particles were too small for mineral classification; however, they have high organic matter content based on the unit's dark brown color. Silt and sand largely consist of well-rounded to subangular and poorly sorted quartz, organic matter, muscovite, biotite, potassium feldspar and iron minerals. The cobble- to boulder-sized material consists of well-rounded to subangular and poorly sorted quartz and metamorphic rock (schist) fragments. Samples did not effervesce when in contact with hydrochloric acid. The clay and silt matrix has low to moderate cohesion, which increases downward throughout the unit as clay content increases. The unit generally coarsens upward from clay and silt at its base to cobbles and boulders at its top. Unit 9 has small laminations (less than 0.1 inch) of clay and silt at its base and contains human-made objects (boots, baskets, floorboards). 
Unit 9 was distinguished by its human-made objects and large boulders, the largest observed among all units, at the top of the unit. Human-made objects seemed to be remnants of Chinatown that were buried by flooding events and subsequent reconstruction. The thickness of unit 9 was not mapped because the trench did not reach its bottom; however, the mapped thickness, obtained from the RTK survey, ranges from 0.29 to $2.60 \mathrm{ft}$, with a mean of $1.38 \mathrm{ft}$. The maximum measured thickness was in block B (inset $D$, sheet 1).

\section{References Cited}

Black Hills National Forest, 2008, Black Hills National Forest boundary: Black Hills National Forest digital data, accessed April 2020 at https://www.fs.usda.gov/detail/blackhills/ landmanagement/gis/?cid=stelprdb5112487.

Carter, J.M., Driscoll, D.G., and Hamade, G.R., 2001a, Estimated recharge to the Madison and Minnelusa aquifers in the Black Hills area, South Dakota and Wyoming, water years 1931-98: U.S. Geological Survey Water-Resources Investigations Report 2000-4278, 66 p. [Also available at https://doi.org/10.3133/wri004278.]

Carter, J.M., Driscoll, D.G., Hamade, G.R., and Jarrell, G.J., 2001b, Hydrologic budgets for the Madison and Minnelusa aquifers, Black Hills of South Dakota and Wyoming, water years 1987-96: U.S. Geological Survey Water-Resources Investigations Report 2001-4119, 53 p. [Also available at https://doi.org/10.3133/wri014119.]

Cohen, K.M., Finney, S.C., Gibbard, P.L., and Fan, J., 2019, International chronostratigraphic chart (ver. 2019/05): International Commission on Stratigraphy, 1 p., accessed August 2019 at https://stratigraphy.org/icschart/ ChronostratChart2019-05.pdf.

Compton, R.R., 1985, Geology in the field: John Wiley \& Sons, $398 \mathrm{p}$.

Deadwood Chamber of Commerce, 2020, History timeline: Deadwood Historic Preservation Commission web page, accessed April 2020 at https://www.deadwood.com/history/ history-timeline/.

Driscoll, D.G., Bunkers, M.J., Carter, J.M., Stamm, J.F., and Williamson, J.E., 2010, Thunderstorms and flooding of August 17, 2007, with a context provided by a history of other large storm and flood events in the Black Hills area of South Dakota: U.S. Geological Survey Scientific Investigations Report 2010-5187, 139 p. [Also available at https://doi.org/10.3133/sir20105187.]
Feldman, R.M., and Heimlich, R.A., 1980, The Black Hills: Kent, Ohio, Kent State University, Kendall/Hunt Publishing Company, K/H Geology Field Guide Series, 190 p.

Freeman, T., 2009, Procedures in field geology: John Wiley \& Sons, $128 \mathrm{p}$.

Lawrence County, 2020, dwd_bnd: Lawrence County geographic information system dataset, accessed April 2020 at https://www.lawrence.sd.us/366/GIS-Data.

Lisenbee, A.L., Redden, J.A., and Fahrenback, M.D., 2015, Geologic map of the Deadwood north quadrangle, South Dakota: South Dakota Department of Environment and Natural Resources, scale 1:24,000.

National Geodetic Survey, 2020a, Geoid models: National Geodetic Survey web page, accessed April 2020 at https://geodesy.noaa.gov/GEOID/.

National Geodetic Survey, 2020b, OPUS - Online Positioning User Service, ver. 2.6 (January 13, 2020): National Geodetic Survey web page, accessed April 2020 at https://www.ngs.noaa.gov/OPUS/.

Redden, J.A., and DeWitt, E., 2008, Maps showing geology, structure, and geophysics of the central Black Hills, South Dakota: U.S. Geological Survey Scientific Investigations Map 2777, 44-p. pamphlet, 2 sheets.

Rydlund, P.H., Jr., and Densmore, B.K., 2012, Methods of practice and guidelines for using survey-grade Global Navigation Satellite Systems (GNSS) to establish vertical datum in the United States Geological Survey: U.S. Geological Survey Techniques and Methods, book 11, chap. D1, 102 p. with appendixes. [Also available at https://doi.org/10.3133/tm11D1.]

South Dakota GIS Data, 2017, Downloadable local roads: South Dakota Department of Transportation digital data, accessed April 1, 2020, at https://opendata201709-18t192802468z-sdbit.opendata.arcgis.com/datasets/ f63b4835c188471686326fb9f2b64359_0?geometry=$121.035 \% 2 \mathrm{C} 41.459 \% 2 \mathrm{C}-79.221 \% 2 \mathrm{C} 46.965$.

Topcon, 2020, Topcon tools 8 (previously available): Topcon Totalcare web page, accessed April 2020 at http://www.topconcare.com/en/software/office-applications/ topcon-tools- $8 /$.

U.S. Geological Survey Geologic Names Committee, 2018, Divisions of geologic time-Major chronostratigraphic and geochronologic units: U.S. Geological Survey Fact Sheet 2018-3054, 2 p. [Also available at https://doi.org/10.3133/ fs20183054.] 

For more information about this publication, contact:

Director, USGS Dakota Water Science Center 821 East Interstate Avenue, Bismarck, ND 58503 1608 Mountain View Road, Rapid City, SD 57702

605-394-3200

For additional information, visit: https://www.usgs.gov/centers/dakota-water

Publishing support provided by the Rolla and Tacoma Publishing Service Centers 
